Mississippi College School of Law

MC Law Digital Commons

Journal Articles

Faculty Publications

2014

Personal Guarantees and Sureties between Commercial Law and Consumers in the United States

Christoph Henkel

Mississippi College School of Law, henkel@mc.edu

Follow this and additional works at: http://dc.law.mc.edu/faculty-journals

Part of the Commercial Law Commons

Recommended Citation

62 Am. J. Comp. L. 333 (2014).

This Article is brought to you for free and open access by the Faculty Publications at MC Law Digital Commons. It has been accepted for inclusion in Journal Articles by an authorized administrator of MC Law Digital Commons. For more information, please contact walter@mc.edu. 


\title{
CHRISTOPH HENKEL*
}

\section{Personal Guarantees and Sureties between Commercial Law and Consumers in the United States†}

\author{
TopIC III. A
}

Guaranties and suretyships reduce the risk of default and today remain essential arrangements in many commercial and consumer transactions. A guarantor or surety promises to pay for the debt of a third party and may become primarily liable on that debt. Despite the significance of such a promise and the resulting obligation, U.S. law does not clearly distinguish between a guarantor and surety in a consumer or commercial context. This is of particular relevance, because in a consumer context a guaranty often has a gratuitous or sentimental element and a guarantor may not always be fully aware of the risks and liabilities involved with a guarantee promise. U.S. law generally considers guaranties and suretyships simply as third-party beneficiary contracts to which common law contract principles apply. This, in turn, makes guaranties and suretyships primarily a state law concern, resulting in significant differences of suretyship laws among all U.S. jurisdictions. As such, the U.S. lacks a uniform body of law in this area and makes consumer protection in a guaranty and suretyship context perfunctory at best.

\section{INTRODUCTION}

Guaranties and sureties are known as some of the oldest concepts of securing a debt and are common in both civil and commonlaw jurisdictions. ${ }^{1}$ Both concepts function as a security mechanism

* Associate Professor of Law, Mississippi College School of Law. Assessor iuris, University of Wisconsin, L.L.M., S.J.D. Professor Henkel is the Co-Director of the International and Comparative Law Center at the Mississippi College School of Law and teaches Domestic and International Commercial Law, Banking Law, Bankruptcy, and European Union Law. The author would like to acknowledge the support provided by Mississippi College School of Law on this project.

$\dagger$ DOI: http://dx.doi.org/10.5131/AJCL.2013.0028

1. William H. Woods, Historical Development of Suretyship from Prehistoric Custom to a Century's Experience with the Compensated Corporate Surety, in EDwARD G. Gallagher, The Law of Suretyship, 3-7 (2d ed.) (2000); E. Sturges, Suretyship and Guaranty, 14 Encyc. Soc. Sci. 482-87 (1954); William W. Buckland, The Main InSTITUTIONs of Roman Law, 320 (1931). 
for creditors, giving them the right to seek satisfaction from more than one person and incidentally reducing the risk of default. In the United States, guaranty and suretyship laws have primarily evolved from common law, but are also outlined in various statutes. ${ }^{2}$ Today, all U.S. States have enacted specific statutes defining the legal requirements for guaranties and sureties in their respective jurisdictions. $^{3}$ Some jurisdictions distinguish between suretyships and guaranties; others have abolished any difference between them. For example, California, ${ }^{4}$ Texas, ${ }^{5}$ Pennsylvania, ${ }^{6}$ Georgia, ${ }^{7}$ Oklahoma, ${ }^{8}$ and South ${ }^{9}$ and North Dakota ${ }^{10}$ no longer distinguish between a guaranty and a surety. The same applies to the Uniform Commercial Code (U.C.C.), which stipulates that a "'[s]urety" includes a guarantor or other secondary obligor."11 On the other hand, the Restatement Third of Suretyship and Guaranty (Restatement 3rd), ${ }^{12}$ as one of the most pervasive authorities in this area, ${ }^{13}$ maintains the distinction between guaranty and suretyship contracts. ${ }^{14}$

2. The Law of Guaranties: A Jurisdiction-by-Jurisdiction Gutde to U.S. and Canadian Law, Commercial Finance Committee Uniform Commercial Code Committee, ABA Business Law Section (Jeremy S. Friedberg, et al., eds., 2013) [hereinafter THE LAw OF GUARANTIES].

3. Id.

4. Cal. Civ. Code Ann. $\$ 2787$ (2005)("The distinction between sureties and guarantors is hereby abolished").

5. Tex. Bus. \& Com. Code Ann. §\$34.01-34.05 (Vernon 1987) ("'surety' includes endorser, guarantor, drawer of draft which has been accepted, and every other form of suretyship, whether created by express contract or by operation of law").

6. Pa. Stat. Ann. tit. $8 \$ 1$ (Purdon 1993)("Every written agreement hereafter made by one person to answer for the default of another shall subject such person to the liabilities of suretyship, and shall confer upon him the rights incident thereto, unless such agreement shall contain in substance the words: 'This is not intended to be a contract of suretyship,' or unless each portion of such agreement intended to modify the rights and liabilities of suretyship shall contain in substance the words: "This portion of the agreement is not intended to impose the liabilities of suretyship'").

7. O.C.G.A. §10-7-1 (2004); See also Equifax, Inc. v. 1600 Peachtree, LLC., 268

Ga. App. 186; 601 S.E. 2d 519.

8. 15 Okl. St. $\$ 378(2004)$.

9. S. Dak. C.L. $§ 56-2-4(2003)$.

10. N.D. Cent. Code \$22-03-07 (2005).

11. U.C.C. § 1-201(b)(39).

12. American Law Institute, Restatement of the Law, Third, Suretyship and Guaranty (1996) [hereinafter Restatement 3d].

13. Id. Ch. 1, Introductory Note, at 3.

14. Restatement $3 \mathrm{~d}$, supra note $12, \S 15$. The Restatement defines an agreement as a guaranty:

if the parties to a contract identify one party as a "guarantor" or the contract as a "guaranty," the party so identified is a secondary obligor and the secondary obligation is, upon default of the principal obligor on the underlying obligation, to satisfy the obligee's claim with respect to the underlying obligation.

Id. $\$ 15(\mathrm{a})$. On the other hand, an agreement is considered a surety under the Restatement

if the parties to a contract to which the principal obligor and secondary obligor are both parties identify one party as a "surety," or the contract as a 
This approach is followed by a majority of states. ${ }^{15}$ Regardless, guaranty and suretyship law the United States lack an overall uniform body of law. While the Restatement 3rd and the U.C.C. provide the uniform framework, significant differences exist throughout all U.S. jurisdictions. For example, not all U.S. States share the same antideficiency statutes, recognize community property or continuing guaranties and waivers. ${ }^{16}$ It is beyond the scope of this article to analyze all of these different state laws. Reference to state laws will be made where necessary to explain specific concepts. Most importantly, it should be noted that U.S. law does not clearly distinguish between consumer and commercial guaranty or suretyship contracts. ${ }^{17}$ In the United States, a personal guaranty does not necessarily involve a consumer transaction, ${ }^{18}$ but may be more easily distinguished from an obligation in rem. ${ }^{19}$

\section{Guaranty and Suretyship as Different Concepts}

A broad definition of a suretyship may include a guaranty. ${ }^{20}$ Guaranty and suretyship contracts involve at least three parties: the creditor, principal and surety, or guarantor. ${ }^{21}$ As such, all of these contracts are tripartite agreements including the promise to answer for the debt of another. Regardless of these basic similarities, a suretyship and guarantee agreement may also be distinguished. ${ }^{22}$

"suretyship" contract, the party so identified is a secondary obligor who is subject to a secondary obligation pursuant to which the secondary obligor is jointly and severally liable with the principal obligor to perform the obligation set forth in that contract.

Id. $\S 15(\mathrm{c})$.

15. J.P. Morgan Chase Bank, N.A. v. Earth Foods, Inc., 939 N.E.2d 455, 489 (Ill. 2010)(stating that "a suretyship differs from a guaranty").

16. The LAw of Guaranties, supra note 2, at ix.

17. In the U.S., detailed statistical data is only available through membership in The Surety \& Fidelity Association of America, available at http://www.surety.org/? page $=$ StatPlan (last visited Sept. 24, 2013). The data could not be accessed and analyzed for this article.

18. A personal guarantee is most often present in a small business context in which shareholders or other owners may be asked to guarantee a principal obligation, such as a business loan by a bank or other investor. This form of transaction does not qualify as a consumer transaction, which is defined as "a transaction in which (i) an individual incurs an obligation primarily for personal, family, or household purposes, (ii) a security interest secures the obligation, and (iii) the collateral is held or acquired primarily for personal, family, or household purposes. The term includes consumergoods transactions." U.C.C. $\$ 9-102$ (a)(26).

19. Arthur Adelbert Stearns, The Law of Suretyship, §3 (1903).

20. Id., §1; WooDs, supra note 1 , (arguing that a "[g] uaranty is a subdivision of suretyship").

21. Will H. Hall \& Sons, Inc. v. Capitol Indem Corp., 260 Mich. App. at 222; Kinville v. Jarvis Real Estate Holdings, LLC., 38 A.D.3d 125, 833 N.Y.S.2d 773 (4th Dep't 2007).

22. The distinction between a guaranty and a suretyship remain. Specifically, since the Restatement of Securities $\$ 82$ and Cmt. $g$ (1941) have used both terms synonymously. See, i.e., Ellen A. Peters, Suretyship Under Article 3 of the Uniform 
Specifically, a suretyship contract may provide the parties with additional rights and duties. ${ }^{23}$

\section{A. Terms and Definitions}

In the United States, the law on guaranties and suretyships relies on many different terms that are often used interchangeably. It is necessary to first briefly explain the most important terms and to position them in the appropriate context. The distinction between a guaranty or suretyship agreement has already been mentioned and will be explored further below. ${ }^{24}$ This section focuses on the use of terms and definitions as they relate to the parties involved in a guaranty or suretyship agreement.

The "creditor" is also referred to as the "obligee." He is the party to whom a debt or performance is owed as part of the underlying obligation. In addition, the creditor is also a party to the guaranty or suretyship agreement and benefits from the security provided by these agreements. ${ }^{25}$

The "principal" is often called the "obligor," because he is the primary debtor to the creditor and is directly liable on the underlying obligation. The principal also receives the consideration for the primary obligation from the creditor and has the "primary moral and legal obligation" 26 to deliver the promised return performance. In addition, the principal is also referred to as the "principal obligor," the "primary obligor" or the "accommodated party." 27

The terms used for the "guarantor" or "surety" may be the most confusing in U.S. law. While, some U.S. jurisdictions clearly distinguish between both concepts, ${ }^{28}$ the U.C.C. uses the terms "accommodating party,"29 "secondary obligor,"30 "indorser,"31 or "co-

Commercial Code, 77 YALE L.J. 833, 841 n. 41 (1967-1968); see also RESTATEMENT 3d, supra note $12, \S 1$, Cmt. c.

23. Restatement 3d, supra note $12, \S 15$, Cmn. d.; See also, Laurence P. Simpson, Handbook on the Law of Suretyship §5, at 8-9 (1950); Schmidt v. McKenzie, 215 Minn. 1, 9 N.W.2d 1 (1943).

24. See supra note 14.

25. Exceptions apply where a guaranty or surety is required by statute. See, e.g., Lobak Partitions v. Atlas Constr. Co., 749 P.2d 716 (Wash. Ct. App. 1988) (noting that the lack of privity may not preclude a creditor to draw on a contractor's bond).

26. Bradley v. Bentley, 231 Ala. 28, 163 So. 351, 354 (1935).

27. U.C.C. \$ 3-103 (11) ("Principal obligor,' with respect to an instrument, means the accommodated party or any other party to the instrument against whom a secondary obligor has recourse under this article").

28. See J.P. Morgan Chase, N.A., 939 N.E.2d at 474.

29. U.C.C. $\$ 3-419$ (a) and Cmt. 1 ("(a) If an instrument is issued for value given for the benefit of a party to the instrument ('accommodated party') and another party to the instrument ('accommodation party') signs the instrument for the purpose of incurring liability on the instrument without being a direct beneficiary of the value given for the instrument, the instrument is signed by the accommodation party "for accommodation"'). 
maker." ${ }^{2}$ In short, a "guarantor" means the person who becomes secondarily liable for another's debt or performance. A "surety," on the other hand, is the person that becomes primarily responsible for the debt and the default of another person. To add to this confusion, some state jurisdictions define sureties as joint makers of notes, bills, bonds, or contracts for the payment of money. ${ }^{33}$

\section{B. Guaranty}

A guaranty is a collateral promise by the guarantor to act as a secondary obligor for the principal in case of default. ${ }^{34}$ As such, a guaranty is an accessorial agreement made between the creditor and a third party, which is not the principal. In other words, the guarantor acts on behalf of the principal by promising or guaranteeing that the principal obligation will be satisfied. At the same time, the guarantor is not a party to the contract creating the underlying obligation. ${ }^{35}$ Rather, the agreement between the creditor and guarantor is separate or independent from the underlying obligation. ${ }^{36}$ As a result, the guarantor's liability to the creditor does not become absolute until the principal defaults ${ }^{37}$ and the guaranty is only a collateral or secondary promise to secure the debt of another person. $^{38}$

30. See supra note 27; See also Restatment 3d \$1 Cmt. c,(stating that "[a]though there are important differences between the two mechanisms [guaranties and suretyships] that should not be obscured, these differences relate to the duties contractually imposed on the secondary obligor by the secondary obligation and not to the nature of the rights inherent in suretyship status.").

31. See supra note 29 ("An accommodation party will usually be a co-maker or anomalous endorser"); See also Johnson v. AgSouth Farm Credit, 267 Ga. App. 567, $600(2004)$

32. Id.

33. Code of Ala. §8-3-1 (2004).

34. General Phoenix Corp. v. Cabot, 300 N.Y. 87, 89 N.E.2d 238 (1949); Nat'l Union Fire Ins. Co. v. Robert Christopher Assoc. 257 A.D.2d 1, 691 N.Y.S.2d 35 (1st Dept. 1999).

35. Restatement 3d, supra note $12, \S 17$ and Cmt. a.

36. Williams v. Sandman, 187 F.3d 379, 382 (4th Cir. 1999) (" $[\mathrm{A}]$ guaranty of payment is an obligation separate and distinct from the original note"); McDonald v. Nat'l Enters., Inc., 262 Va. 184, 547 S.E. 2d 204 (2001) (noting that a "guaranty is an independent contract").

37. Plunkett v. Davis Sewing-Mach. Co., 84 Md. 529, 533, 36 A. 115 (1897).

38. See J.P. Morgan Chase N.A., 939 N.E.2d at 487(stating that "A guaranty is a collateral undertaking, an obligation in the alternative to pay the debt if the principal does not"); See also Byrd v. Estate of Nelms, 2004 Tex. App. Lexis 10351 (Nov. 17, 2004) (noting that a guaranty creates a secondary obligation and that the guarantor is liable if the primary obligor fails to perform), Cook v. Dykstra, 800 S.W. $2 \mathrm{~d} 556$ (Tex. Ct. App. 1990), Chiles, Heider \& Co. v. Pawnee Meadows, Inc., 217 Neb. 315, 350 N.W. 2d. 1 (1984). 


\section{The Liability of a Guarantor}

Under U.S. law, a guaranty is not required to be absolute and may be limited. The most common limitations of the guarantor's liability are contingent guaranties, which may include the guaranty of collection or the guaranty of payment.

\section{a. Contingent guaranty}

In general, a contingent guaranty requires the occurrence of a contingent event before a guarantor will be held liable on the guaranty. ${ }^{39}$ The contingent event is typically a condition precedent that needs to be met before the liability is triggered. The most important example of such a contingent guaranty is the guaranty of collection, but may be any condition agreed upon by the parties. ${ }^{40}$ For example, a condition may be to hold a letter of credit or to secure a second personal guaranty from a corporate officer. ${ }^{41}$ Conditions may also include certain inspection requirements for delivered goods, volumes of goods used or specific payment terms to be met. ${ }^{42}$ Other examples may include the requirement to provide notice to a guarantor. ${ }^{43}$

\section{b. Guaranty of collection}

The guaranty of collection is the most important example of a contingent or conditional guaranty in the U.S. Under a guaranty of collection, the guarantor becomes liable only after the creditor fails to secure payment from the principal obligor. ${ }^{44}$ In order to collect from the guarantor the creditor must not only prove "that he has taken legal action against the principal and has been unable to collect, but also that he exercised "due diligence ... in enforcing his legal remedies against the debtor." 45 A guaranty of collection does not require any specific form. It is sufficient if it states that payment will only be

39. Lawndale Steel Co. v. Appel, 98 Ill. App. 3D 167, 170 (1981).

40. Other examples of contingent guaranties are the so-called "springing" or "insider" guaranties. Both forms are not primarily utilized to assure payment, but cooperative behavior by the principal instead. A "springing" or "insider" guaranty include the threat to hold those who control the debtor liable on their personal guaranties. See, i.e, Marshall E. Tracht, Insider Guaranties in Bankruptcy: A Framework for Analysis, 54 U. Miami L. Rev. 497 (2000).

41. See Lawndale Steel Co., 98 Ill. App. 3D at 170.

42. McKnight v. Virginia Mirror Co., 463 S.W.2d 428, 429 (Tex. 1971).

43. Whitehead v. Derwinski, 904 F.2d 1362, 1364 (9th Cir. 1990) (dealing with the interaction of federal and state laws when seeking indemnification from veterans default on certain home loans guaranteed by VA programs).

44. Paul W. Brandt, The Law of Suretyship and Guaranty, 241-49 (1905); see also General Phoenix Corp., 300 N.Y. at 89 (stating that a guarantor binding himself to pay only after all attempts to obtain payment have failed becomes a guarantor of collection); Carrier Brokers, Inc. v. Spanish Trail, 751 P.2d 258 (Ut. Ct. App. 1988).

45. Mullan v. Randall, 100 A.D.2d 737, 1984 N.Y. App. Div. LEXIS 17738. But see, Leaseway System Corp. v. Rushmore \& Weber, Inc., 93 A.D.2d 318, 463 N.Y.S.2d 92 (3d Dept. 1993) (Noting that a creditor may not be required to take legal actions if they would obviously be futile). 
made after reasonable attempts of collection have been made against the principal obligor. ${ }^{46}$

\section{c. Guaranty of payment}

A guaranty of payment creates the same liability as a suretyship. ${ }^{47}$ Conceptually, the guaranty of payment is a collateral promise, but as the suretyship it is unconditional as long as the underlying obligation involves the payment of a debt. Unlike the guaranty of collection, the guaranty of payment does not require a condition precedent to be met. ${ }^{48}$ It is simply an obligation to pay the debt of another when due and if the principal obligor defaults. ${ }^{49}$ As a result, a guarantor of payment is primarily liable and waives the requirement that a creditor must first take actions against the principal. ${ }^{50}$ As with the guaranty of collection, the guaranty of payment has no specific form requirement. While it is sufficient to recite that the guaranty is a guaranty of payment, in order to be enforceable the intent of the guarantor must be clearly expressed. ${ }^{51}$

\section{Time and Performance Limitations}

The time of performance for any guaranty may also be limited. For example, a guaranty can be executed for a single transaction or for a predetermined period of time. The former guaranty is often defined as a temporary, the latter as a continuing guaranty. ${ }^{52}$ Unless clearly defined in the guaranty contract the determination of the time of performance may be difficult, however. ${ }^{53}$ The clear intent of the parties is therefore the single most important factor to determine the duration of any guaranty in the United States.

46. Cox v. Lerman, 949 S.W.2d 527, 530 (1997) (In Cox the guaranty stated "If after reasonable attempts Mrs. Egan is unable or refuses, I will pay your bills for court appearances").

47. Homewood People's Bank v. Hastings, 263 Pa. 260 (1919) (finding that an instrument guaranteeing payment is a suretyship).

48. United States v. Vahlco Corp., 800 F. 2d 462, 466 (1986).

49. Ford v. Darwin, 767 S.W.2d 851, 854 (1989); Int'l Harvester Credit Corp. V. Leaders, 818 F.2d 655(8th Cir. 1987) (For payment on a guaranty of payment, Iowa does not require the creditor to await a final judgment in the bankruptcy proceeding of the principal).

50. See Mullan, 100 A.D.2d at 737; Rodehorst v. Gartner, 669 N.W.2d 679 (Neb. 2003); Kent Feeds, Inc. v. Manthei, 646 N.W.2d 87 (Iowa 2002) (Without pursuing alternative dispute resolution against the principal obligor, mortgagee could bring suit against guarantor).

51. General Phoenix Corp., 300 N.Y. at 87.

52. Resolution Trust Corp. v. Marshall, 939 F.2d 274, 277 (5th Cir. 1991) (Noting that "a specific guaranty applies to one particular transaction or loan, while a continuing transaction applies to the original transaction and any extensions or renewals").

53. Skrypek v. St. Joseph Valley Bank, 469 N.E.2d 774, 777 (Ind. Ct. App. 1984) (Despite a clear intent, ambiguities in a contract may required to interpret a guaranty as a continuing guaranty). 


\section{a. Continuing guaranty}

A continuing guaranty is not limited to one specific transaction, but instead contemplates a future course of dealings, covering a series of transactions. ${ }^{54}$ In other words, a continuing guaranty contemplates "a succession of liabilities, for which, as they accrue, the guarantor becomes liable." 55 If the intent of the parties is unclear and ambiguities exist in the guaranty contract, a continuing guaranty is the default option. ${ }^{56}$ The language of the guaranty and the surrounding circumstances determine intent. ${ }^{7}$ More specifically, the guarantor is a "favorite of the law," 58 and any uncertainty as to the meaning of his contract of guaranty should be resolved in his favor. ${ }^{59}$ The starting point for analyzing the rights and duties of the parties is therefore the specific language of the instrument. ${ }^{60}$ It should be noted, however, that any continuing guaranty is considered a rolling or continuously renewing offer to be accepted by the creditor for any future transaction ${ }^{61}$ and remains valid until revoked or effectively extinguished. ${ }^{62}$

\section{b. Temporary guaranty}

The second performance limitation of a guaranty is a temporary guaranty, which secures only one act or single transaction. ${ }^{63}$ "If by its terms [the guaranty] is confined to a single transaction, liability thereon ceases with execution of performance of that transaction." 64

54. Vidimos Inc. v. Vidimos, 456 N.E.2d 455, 458 (1983); See also, Restatement $3 \mathrm{~d}$, supra note $12, \S 16$ ("A continuing guaranty is a contract pursuant to which a person agrees to be a secondary obligor for all future obligations of the principal obligor to the obligee").

55. See Blount v. Westinghouse Credit Corp., 432 S.W.2d 549, 553.

56. See Vidimos Inc., 456 N.E.2d at 458.

57. R.N. Nason \& Co. v. Kennedy, 40 Cal. App. 159, 162 (1919); Goldman v. Dangerfield, 101 Cal. App. 67, 75 (1929) (The intention may be gathered from the instrument itself or from the course of dealings between the parties).

58. Southwest Savings Association v. Dunagan, 392 S.W. 2d 296, 297 (Tex. Civ. App. Dallas 1965).

59. FDIC v. Woolard, 889 F.2d 1477, 1480 (5th Cir. 1989); But see Bartmann v. Maverick Tube Corp., 853 F.2d 1540, 1545 (10th Cir. 1988) ("Guaranties are most strongly construed against the guarantor").

60. Id.

61. Prize Steak Prods. V. Bally Tom Foolery, Inc., 717 F.2d 367 (7th Cir. 1983); See also, REstatement 3d, supra note $12, \$ 16$, Cmt. a. ("[A] continuing guaranty is sometimes described as a series of offers to become a secondary obligor. . .").

62. Generally, a guarantor has the unilateral power to terminate any continuing guaranty before the creditor effectively accepts or relies on it for any subsequent transaction. See, e.g., FDIC v. Manion, 712 F.2d 295, 298 (7th Cir. 1983)(Revocation of a continuing guaranty before the extension of the underlying obligation); See also, First New Jersey Bank v. FLM Business Machines, Inc., 325 A.2d 843, 848-50 (1974); RESTATEMENT 3d, supra note 12, \$16 ("A continuing guaranty is terminable ...").

63. Holmes v. Elder, 170 Tenn. 257, 264 (1936)("A guaranty may be continuing, or may be exhausted by one act").

64. $I d$. 
As noted before, ${ }^{65}$ the determination on whether the parties agreed to a temporary or continuing guarantee depends not only on the actual intention of the parties, but centers on principles of construction applied to contract law. The case law is inconsistent, some courts rely on a strict interpretation of the contract within its four corners and require an express agreement on continuity. ${ }^{66}$ On the other hand, a number of other courts construe guaranty contracts against the guarantor and in favor of the creditor. ${ }^{67}$

\section{General and Special Guaranties}

Under U.S. law, a guaranty may also be categorized as a general of special guaranty. A general guaranty is addressed to an undefined or unlimited group of persons. ${ }^{68}$ Any creditor to whom the guaranty is presented and who relied on it, may enforce the guaranty. ${ }^{69} \mathrm{~A}$ general guaranty may also be assigned and the assignee making advances on the guaranty may be protected. ${ }^{70}$

A special guaranty, on the other hand, is only addressed to a particular entity or person and only the named or specifically described obligee acquires any rights under the guarantee. ${ }^{71}$ Typically, the original creditor is the sole addressee and the guaranty cannot be assigned or transferred. ${ }^{72}$

\section{Form Requirements and Other Rules of Construction}

\section{a. Statute of frauds}

U.S. law requires that all guaranty and suretyship contracts must be in writing. Except for Louisiana, ${ }^{73}$ all U.S. jurisdictions follow the Statute of Frauds and require that any agreement "to answer

65. Supra II.2.a. and accompanying text.

66. Trade Bank \& Trust Co. v. Goldberg, 38 A.D.2d 405, 407(1972)(“[A]n instrument of guaranty must be construed as limited to the transaction involved unless it clearly shows a continuing liability").

67. Bartmann, 853 F.2d at 1545; Skrypeck v. St. Joseph Valley Bank, 469 N.E.2d 774 (Ind. Ct. App. 1984).

68. Niederer v. Ferreira, 189 Cal. App. 3d 1485, 1501, 234 Cal. Rptr. 779 (1987).

69. Id.

70. New Holland, Inc. v. Trunk, 579 So. 2d 215, 217 (Fla. Dist. Ct. App. 1991)(“[A] general guaranty is assignable while a special guaranty is generally not assignable ...").

71. Id.

72. Id. See also, FDIC v. Schumacher, 660 F. Supp. 6 (E.D.N.Y. 1984); Finance Am. Private Brands, Inc. v. Harvey E. Hall, Inc., 380 A.2d 1377 (Del. Super. 1977). Note, however, that the case law on assignability of special guaranties is not consistent. Some courts allow assignability after a cause of action has been established. See, e.g., Stokors v. Roth, 887 F. Supp. 265 (D. Kan. 1995). Yet, other courts make assignability dependent on party intent, see, e.g, Sinclair Marketing, Inc. v. Siepart, 695 P.2d 385 (Idaho 1985), or advocate a case to case approach. See, e.g., Essex Int'l, Inc. v. Clemage, 440 F.2d 547 (7th Cir. 1971).

73. La. Civ. Code Art. 3038 (2011) (establishing a statutory writing requirement). 
for the debts, defaults or miscarriages of another" 74 must be in writing to be enforceable. ${ }^{75}$ With the primary purpose of fraud prevention, ${ }^{76}$ the Statute of Frauds has been the subject of much debate in the United States. ${ }^{77}$ Yet, in context of guaranties and suretyships the Statute of Frauds serves a dual purpose. It is evidentiary and "serves the cautionary function of guarding the promisor against ill-considered action." 78

While the writing requirement for guaranty and suretyship contracts is the typical norm, a writing is not required if the guarantor has a personal, immediate and pecuniary interest in the transaction or may himself benefited from the performance. ${ }^{79}$ This so-called "main purpose" or "leading object" rule ${ }^{80}$ eliminates the writing requirement for contracts, because the likelihood of any imbalance between both parties is significantly reduced and the agreement lacks the gratuitous or sentimental element typically present in a guaranty. ${ }^{81}$ Moreover, it can be assumed that the guarantor will receive his own bargained for benefit from the creditor and is promising to pay his own rather than the debt of another. ${ }^{82}$ California explicitly exempts guaranty contracts from a writing requirement if the guaranty "is deemed an original obligation of the promisor." ${ }^{3}$ The determination of whether an original obligation existed is generally a question of fact and proven if the promise to answer for the principal obligor's debt was made for new consideration directly benefiting the guarantor. ${ }^{84}$

74. Also known as the "suretyship provision," the U.S. Statute of Frauds originates from the English Statute of Frauds under \$4, 29 Charles II, Ch. 3, 1677. See also, Restatement 3d, supra note $12, \S 11$. (1981).

75. American Law Institute, Restatement of the Law, Second, Contracts, $\$ 88$

76. Ian Ayres \& Gregory Ktass, Studies in Contract Law, at 406-10 (8th ed. 2012).

77. Hugh Evander Willis, The Statute of Frauds-A Legal Anachronism, 3 IND. L.J. 427, 429-31 (1928); Karl N. Llewellyn, What Price Contract?-An Essay in Perspective, 40 YALE L.J. 704, 747 (1931).

78. Restatement 3d, supra note $12, \S 11$, Cmt. b.

79. Davis v. Patrick, 141 U.S. 479,487 (1891).

80. Restatement 3d, supra note $12, \S 11$, Cmt. to Subsection (3)(c), k. The Restatement summarizes the rule in $\S 11(3)(\mathrm{c})$ as follows " $(3)(\mathrm{c})$ A contract that all or part of the duty of the principal obligor to the obligee shall be satisfied by the secondary obligor is not within the Statute of Frauds as a promise to answer for the duty of another if the consideration for the promise is in fact or apparently desired by the secondary obligor mainly for its own economic benefit, rather than the benefit of the principal obligor."

81. Id.

82. Id. Excluded from the main purpose rule are contracts of guaranty insurance. See, Restatement 3d, supra note 12 , §11, Cmt. m.

83. Cal. Civ. Code $\$ \$ 2793-2794$.

84. Quadro v. Widemann, 72 Cal. App. 481 (1925); Schumm by Whyner v. Berg, 37 Cal. 2d 174 (1951); Farr \& Stone Ins. Brokers, Inc. v. Lopez, 61 Cal. App. 3d 618 (1976). 


\section{b. Consideration}

To be enforceable, a guaranty contract must be supported by valid consideration. ${ }^{85}$ The consideration can be part of the underlying obligation, ${ }^{86}$ but always requires a new and distinct consideration if the guaranty is not include in the original debt instrument. ${ }^{87}$ "Consideration is shown when the person promising to pay the debt is benefited by the payment of said debt." 88 In certain cases a benefit to the principal obligor and a detriment to the creditor may be sufficient. ${ }^{89}$ The delay of enforcement against the guarantor or the release of any security held for the debt may also be sufficient. ${ }^{90}$

\section{c. Notice}

The notice requirement may be the most important issue in guaranty contracts as it relates to consumer transactions. ${ }^{91}$ Two primary notice requirements should be distinguished in guaranty contracts: the notice of acceptance of the guarantee by the creditor and the notice to the guarantor of the default of the principal obligor. In addition, some special rules exist with regard to installment contract guarantors.

\section{i. notice of acceptance}

Communication of the acceptance of an offer is one of the most fundamental tenets of construction in U.S. contract law. ${ }^{92}$ Unless general exceptions apply, such as in context of unilateral offers or where notice was waived, ${ }^{93}$ an offeror must always have notice of acceptance before any agreement becomes enforceable. ${ }^{94}$

When executing a guaranty, the guarantor typically does not know if the creditor will advance any funds to the principal obligor or perform on the underlying obligation. The guaranty may be just one condition precedent of performance on the underlying obligation or,

85. Bank of Southside Va. v. Candelario, 385 S.E.2d 601(Va. 1989). See also, RESTATEMENT 3d, supra note 12, §9(1).

86. Amato v. Creative Confections Concepts, Inc., 97 F. Supp. 2d 949 (E.D. Wis. 2000); Rheem Mfg. Co. v. Progressive Wholesale Supply Co., 28 S.W.3d 333 (Mo. Ct. App. 2000).

87. Sycoc V. Holmes, 450 S.E.2d 784, 786 (1994).

88. Id. (citing Winkler v. Chesapeake \& Ohio R.R. Co., 12 W. Va. 699, 706 (1878)).

89. Blalock v. Central Bank of Ga., 170 Ga. App. 140, 316 S.E.2d 474 (1984); Rohm \& Haas Co. v. Gainsville Pant \& Supply Co., 225 Ga. App. 441, 483 S.E.2d 888 (1997).

90. Rudio v. Yellowstone Merchandising Corp., 200 Mont. 537, 543-44, 652 P.2d 1163 (Mont. 1982)("Forbearance of a legal right is a sufficient consideration").

91. Richard F. Dole, Notice Requirement of Guaranty Contracts, 62 Mich. L. Rev. 57, 84-85 (1963); Peter A. Alces, The Efficacy of Guaranty Contracts in Sophisticated Commercial Transactions, 61 N.C. L. REv. 655 (1983).

92. Joseph M. Perillo, Calamari and Perillo on Contracts, 62 (6th ed., 2009).

93. Id.

94. Id. 
in case of a promissory note, only become effective after it was delivered. As a result, the guarantor may not be able to reliably determine his liabilities until he receives notice from the creditor.

As a result of differing state law requirements, the case law on notice of acceptance remains inconsistent in the United States. Under Erie Railroad Co. v. Tompkins, ${ }^{95}$ federal courts are required to apply substantive state law and may not prescribe any notice requirement. Some courts look toward principles of contract interpretation to determine the intent of the parties and may rely on the surrounding circumstance of formation to decide whether notice is required. ${ }^{96}$ Others courts view notice as non-essential and reject acceptance as a condition for a guarantor's liability. ${ }^{97}$ While a number of indicators may serve as a predictor of when notice is necessary, ${ }^{98}$ a notice of acceptance may only be explicitly required if the guarantor and creditor agreed to such notice or reliance on notice was created by the creditor. ${ }^{99}$

\section{ii. notice of default}

The U.S. also lacks consistent standards for a notice requirement after default. ${ }^{100}$ Unless otherwise agreed, notice is not necessary for a guaranty of payment. ${ }^{101}$ A guaranty for payment is always unconditional and technically undistinguishable from a suretyship. The same is not true for continuing guarantee. Without any communication between the creditor and the guarantor, the latter will not be able to evaluate his level of liability accurately. ${ }^{102}$ Yet, as a guarantor is often in a personal relationship with the principal, the guarantor may have a better access to information about the principal's default and notice of default may not be necessary. In addition, the guarantor may have various defenses against the creditor, including impairment. ${ }^{103}$

95. Erie Railroad Co. v. Tompkins, 304 U.S. 64 (1938).

96. State Bank of Cologne v. Schrupp, 408 N.E.2d 686, 688-689 (Minn. Ct. App. 1987); Atlanta Newspapers, Inc. v. Taylor, 104 Ga. App. 707, 709 (1961).

97. Linares v. Banco Cent. S.A., 581 So. $2 d 248$ (Fla. Dist. Ct. App. 1991); Upshaw v. Southern Wholesale Flooring Co., 197 Ga. App. 511 (Ga. Ct. App. 1990); Westchester Fire Ins. Co. v. Campbell, 55 F.3d. 32 (1st Cir. 1995).

98. Richard F. Dole, Notice Requirement of Guaranty Contracts, 62 MicH. L. REv. 57, 84-85 (1963).

99. RESTATEMENT 3d, supra note $12, \S 8$, Cmt. a ("Notification is not essential to acceptance . . . unless the offer manifests a contrary intention").

100. Seronick v. Levy, 527, N.E.2d 746 (Mass. Ct. App. 1988); Long v. NCNB-Texas Nat'l Bank, 882 S.W.2d 861 (Tex. Ct. App. 1994).

101. Dev. Co. v. Lichter, 191 Cal. App. $3 d 933$ (1987).

102. Citi-Lease Co. v. Entm't. Family Style, Inc., 825 F. 2d. 1497 (11th Cir. 1987).

103. Restatment 3d §§ 37-45. 
iii. notice in consumer credit transactions

Despite the inconsistent case law on notice for acceptance and default, a number of mandatory notice requirements have been adopted in the United States in context of consumer credit transactions.

The first and maybe most explicit example is $\S 3.208(1)$ of the Uniform Consumer Credit Code (UCCC), ${ }^{104}$ which establishes that

A natural person, other than the spouse of the consumer, is not obligated as a co-signer, co-maker, guarantor, indorser, surety, or similar party with respect to a consumer credit transaction, unless before or contemporaneously with signing any separate agreement of obligation or any writing setting forth the terms of the debtor's agreement, the person receives a separate written notice that contains a completed identification of the debt he may have to pay and reasonably informs him of his obligation with respect to it.

The notice requirement in the UCCC is the direct result of a concern expressed in the 1972 Report of the National Commission on Consumer Finance. ${ }^{105}$ Namely, that "persons who assist consumers in obtaining credit by lending their signatures as sureties, or otherwise, may not understand the consequences of their act." 106 Under the UCCC, a guarantor of a consumer credit transaction must therefore be given a separate notice informing him of his potential liabilities. ${ }^{107}$ In addition, the accommodation party must also be given a copy of the underlying obligation agreement. ${ }^{108}$ However, as of fall 2013, only eleven U.S. states and Guam have enacted the UCCC. ${ }^{109}$

The second example for an independent notice requirement is a rule promulgated by the Federal Trade Commission in context of consumer credit transactions, such as installment retail sales. ${ }^{110} \$ 444.3$ (2) states that it is an unfair act or practice for

a lender or retail installment seller, directly or indirectly, to obligate a cosigner unless the cosigner is informed prior to

104. Uniform Consumer Credit Code (1974) [hereinafter UCCC], available at http:/ /www.uniformlaws.org/shared/docs/Consumer\%20Credit\%20Code/UCCC1974.pdf (last visited Sept. 16, 2013).

105. National Commission on Consumer Finance, Consumer Credit in the United States: The Report of the National Commission on Consumer Finance (Washington D.C., U.S. Government Printing Office, 1972).

106. Id. at $39-40$.

107. UCCC, Comment to $\$ 3.208$.

108. Id.

109. The UCCC is enacted in Colorado, Idaho, Indiana, Iowa, Kansas, Maine, Oklahoma, South Carolina, Utah, Wisconsin, Wyoming, and Guam.

110. 16 C.F.R. Part 444.3; 49 Fed. Reg. 7,789 (Mar. 1, 1984). 
becoming obligated, which in the case of open end credit shall mean prior to the time that the agreement creating the cosigner's liability for future charges is executed, of the nature of his or her liability as cosigner. ${ }^{111}$

In order to prevent any unfair or deceptive act or practices the lender or installment retail seller is required to give the cosigner notice and provide him with a separate document that contains the following statement:

\section{Notice to Cosigner}

You are being asked to guarantee this debt. Think carefully before you do. If the borrower doesn't pay the debt, you will have to. Be sure you can afford to pay if you have to, and that you want to accept this responsibility.

You may have to pay up to the full amount of the debt if the borrower does not pay. You may also have to pay late fees or collection costs, which increase this amount.

The creditor can collect this debt from you without first trying to collect from the borrower. The creditor can use the same collection methods against you that can be used against the borrower, such as suing you, garnishing your wages, etc. If this debt is ever in default, that fact may become a part of your credit record.

This notice is not the contract that makes you liable for the debt. ${ }^{112}$

In addition to the abovementioned notice requirements, a number of U.S. states have implemented similar rules. Illinois and New York are just two examples. ${ }^{113}$ In Illinois, the cosigner must be provided with a copy of an installment contract and a separate cosigner statement informing him about his obligations and liabilities as a guarantor. ${ }^{114}$ In addition, the cosigner and guarantor are required to execute the cosigner statement in order to create an enforceable guaranty. 115 The seller or holder must also first proceed against the primary obligor in court before being able to draw on the guaranty. ${ }^{116}$

111. Id. The FTC defines cosigners as "[a] natural person who renders himself or herself liable for the obligation of another person without compensation;" Id. at $\S 444.2(\mathrm{k})$.

112. Id. at $\$ 444.3(\mathrm{c})$.

113. Ill. Stat. Ann. ch. 121 1/2, $\$ 519$ and $\S 578$; N.Y. Pers. Prop. Law $\S 313$ and $\S 420$.

114. Ortega v. Mertit Ins. Co., 433 F. Supp. 135, 139-40 (W.D. Ill. 1977).

115. Id.

116. American Buyers Club of Mt. Vernon, Ill., Inc. v. Zuber, 15 Ill. Dec. 440; 373 N.E.2d 786 (App. Ct. 1978). 
While not as detailed, New York law generally follows the same approach. ${ }^{117}$

\section{d. Other important rules of construction}

As noted, the general rules of construction for contracts apply to guaranty contracts in the United States and regardless of whether the parties are consumers. The use of the word "guaranty" is not required as long as the language of the contract clearly indicates that the guarantor's intention is to be bound to the creditor for the debt of the principal obligor. ${ }^{118}$ However, not every expression or assurance may qualify as a guaranty. For example, the assertion "[y]ou may rest assured that you will get your pay for all your work" 119 or "[y]ou can feel sure that we will live up to this agreement, even if I have to pay you personally" 120 is not sufficient and may simply be considered a gratuitous offer. Overall, the intent of the parties is the most important factor to conclude that a contract does qualify as guaranty. ${ }^{121}$

If problems arise because the terms of the guaranty are ambiguous, ${ }^{122}$ the parol evidence rule may apply, ${ }^{123}$ but generally the courts will first try to determine the intention of the parties based on a reasonable interpretation of the terms of the agreement. ${ }^{124}$ Considerable inconsistencies remain, however, on whether courts in the United States should always construe a guaranty in favor of the guarantor $^{125}$ or in favor of the creditor. ${ }^{126}$

117. N.Y. Pers. Prop. Law $\$ 313$ and $\$ 420$. There are two possible differences when compared to Illinois law. First, New York seems to allow a guaranty of payment. Id. at $\$ 420(b)$. Second, under New York law, future or continuing guaranties are not allowed in motor vehicle installment contract and limited to two years in all others. Id. at $\$ 313$.

118. Brewster Transit Mix Corp. v. McLean, 565 N.Y.S.2d 316 (App. Div. 1991); Marine Midland Bank, N.A. v. Elshazly, 753 F. Supp. 20 (D. Conn. 1991); Fortmeyer v. Summit Bank, 565 N.E.2d 1118 (1991).

119. Switzer v. Baker, 95 Cal. 539, 540 (1892).

120. Keane v. Gartell, 334 F.2d 556, 557 (D.C. Cir. 1964).

121. Texas Commerce Bank Nat'l Ass'n v. Capital Bancshares, Inc., 907 F.2d 1571 (5th Cir. 1990); Bandit Ind., Inc. v. Hobbs Int'l, Inc., 463 Mich. 504, 620 N.W.2d 531 (2001); Morrilton Sec. Bank v. Keleman, 70 Ark. App. 246, 248, 16 S.W. 3d 567, 568 (2000); State Bank of E. Moline v. Cirivello, 839, 386 N.E.2d 43 (1978).

122. In the United States, the determination of whether a contract is ambiguous is a question of law. See, i.e, FDIC v. Carinal Oil Well Serv. Co., 837 F.2d 1369 (5th Cir. 1988); Miller Brewing Co. v. Gregg, 389 F.2d 878 (6th Cir. 1968).

123. C. T. Drechsler, Parol Evidence as Applied to Written Guaranty, 33 A.L.R.2d 960; See also, First Nat'l Bank in Durant v. Honey Creek Entm't Corp., 54 P.3d 100, 105 (2002).

124. Overland Park Savings \& Loan Ass'n v. Miller, 243 Kan. 730, 738 (1988).

125. FDIC v. Neitzel, 769 F. Supp. 346 (D. Kan. 1991); A.D.E., Inc. v. Louis Joliet Bank \& Trust Co., 742 F.2d 395 (7th Cir. 1984); Nat'l Bank of Eastern Arkansas v. Collins, 236 Ark. 822, 826 (1963)("A guarantor, like a surety, is a favorite of the law, and his liability is not to be extended by implication beyond the express limits or terms of the instrument, or its plain intent").

126. AGCO Corp. v. Anglin, 216 F.3d 589, 595 (7th Cir. 2000)(Noting that under Georgia law "ambiguity in a guaranty is construed against the maker."); See also 


\section{Suretyship}

In contrast to a guaranty, a suretyship is a "direct and original undertaking under which the surety is primarily liable with the principal obligor."127 Thus a surety typically becomes jointly and severally liable with the principal obligor and default by the principal is not required to trigger liability. ${ }^{128}$ Despite the fact that the principal obligor retains the primary liability on the underlying obligation, the liability of the surety is coextensive and the creditor has an immediate remedy against both the principal and the surety. ${ }^{129}$

Finally, U.S. law distinguishes between a real and a personal suretyship. If the suretyship includes a promise to answer for the debt of another person the suretyship is considered a personal suretyship. On the other hand, if the surety pledges property or a mortgage as collateral for the debt of another the suretyship is classified as a real suretyship. ${ }^{130}$

\section{Involuntary Suretyship}

A suretyship in the United States typically includes three different express agreements: (1) the underlying obligation, which is the agreement between the principal and the creditor; (2) the suretyship agreement, which is the agreement between the creditor and the surety; and (3) the indemnity agreement between the surety and the principal. The suretyship agreement creates the unconditional secondary obligation of the surety and his promise to pay for the debt of the principal in case of default; it often takes the form of a bond. ${ }^{131}$ Under the indemnity agreement the principal promises the surety to cover any losses the surety incurred in context of the suretyship agreement. As an exception to the express suretyship agreement, a suretyship may, however, also be created by operation of law or as a result of any change in the contractual relationship between the creditor and principal.

JPMorgan Chase Bank, N.A. v. Specialty Rests., Inc., 243 P.3d 8 (Okla. 2010); Wilson v. Kellwood Co., 817 S.W.2d 313, 318 (Tenn. Ct. App. 1991)("A guarantor in a commercial transaction is to be held to the full extent of his engagements, and the rule in construing such an instrument is that the words of the guaranty are to be taken as strongly against the guarantor as the sense will admit.").

127. Middlebrook Tech, LLC, v. Moore, 157 Md. App. 40, 58 (2004).

128. Restatement 3d, supra note $12, \S 1$, Cmt. c.

129. Middlebrook Tech,157 Md. App. at 58 (2004); Atl. Contracting \& Material Co. v. Ulico, $380 \mathrm{Md}$. 285, 844 A2d. 460, 468 (2003)("The liability of a surety is coextensive"); General Motors Acceptance Corp. v. Daniels, 303 Md. 254, 259, 492 A2d. 1306 (1985); Gen. Builders Supply Co. v. MacArthur, 228 Md. 320, 326, 179 A2d. 868 (1962)("Ultimately liability rests upon the principal obligor, rather than the surety, but the obligee has a remedy against both").

130. Honey v. Davis, 930 P.2d 908 (1997).

131. Fid. \& Guar. Ins. Co. v. Keystone Contractors, Inc., 2002 U.S. Dist. LEXIS 15403 (E.D. Pa. Aug. 14, 2002); See also, Marilyn Klinger et al., Contract Performance Bonds, in The Law of Suretyship (Edward G. Gallagher ed., 2nd ed. 2000). 
a. Assumption of debt and pledges

The most common examples of involuntary suretyships include the assumption of a debt by a third party and pledges of property. If a third party assumes the debt, the third party becomes the principal and the original debtor becomes the surety. ${ }^{132}$ The same applies, if the third party assumes an obligation, such as a mortgage. ${ }^{133}$ In the latter case, the party who assumes the mortgage becomes the principal debtor of the mortgagee and the original mortgagor will assume the suretyship.

A pledge of property is another example of an involuntary suretyship. A third party becomes a surety, if he, without assuming any personal obligation, offers or mortgages his property as collateral to secure another person's debt. ${ }^{134}$ The pledge also includes the implied promise by the principal obligor to indemnify the surety notwithstanding the absence of any express written agreement. ${ }^{135} \mathrm{~A}$ similar example is the pledge of a Certificate of Deposit or security when offered as a collateral to secure the debt of another person or corporation. ${ }^{136}$ For example, corporate stockholders may decide to pledge company shares to secure the company's debt. ${ }^{137}$

\section{b. Co-obligors}

Co-obligors are also viewed as involuntary sureties under U.S. law. The typical example involves co-makers or an anomalous indorser ${ }^{138}$ of a negotiable instrument. ${ }^{139}$ While each of the co-obligors or co-makers may be seen as a surety on the underlying obligation, both are also primarily liable on the obligation and not necessarily considered a secondary obligor in relation to the creditor. ${ }^{140}$ Rather, co-obligors are individually liable to the creditor and principal and surety in relation to each other. ${ }^{141}$

132. Club Telluride Owners Ass'n, Inc. v. Mitchell, 70 P.3d 502 (2002); B.S.G. Foods, Inc. v. Multifoods Distrib. Group, Inc., 75 Ark, App. 30 (2001); Westinghouse Credit Corp. v. Wolfer, 88 Cal. Rptr. 654 (1970).

133. Waddell v. Roanoke Mut. Bldg \& Loan Ass'n, 165 Va. 229, 236 (1935); Hofheimer v. Booker, $164 \mathrm{Va}$. 358, 364 (1935).

134. Simpson, supra note 23, at \$18, 31.; See also Honey v. Davis, 131 Wn. 2d 212, 218 (1997).

135. Fluke Capital \& Management Servs. Co., 106 Wn. 2d 614, 620-21 (1986).

136. Frost Nat'l Bank v. Burge, 29 S.W.3d 580 (2000); Securities and Exchange Comm'n v. H.L. Rodger \& Bro., 444 F.2d 1077 (7th Cir. 1971); Mallis v. Faraclas, Md. App., 235 Md. 109 (1964).

137. Id.

138. U.C.C. §3-205(d); See also U.C.C. §3-419, Cmt. 1.

139. U.C.C. $\$ 3-11, \S 3-103(\mathrm{a})(7)$ and $\$ 3-205$

140. U.C.C. $\$ 3-412$.

141. Beneficial Fin. Co. N.Y., Inc. v. Husner, 82 Misc. 2d 550, 552 (Sup. Ct. 1975); Rynkowski v. Seal, 2003 Del. C.P. Lexis 8, 8-9 (Jan. 3. 2003) (Suretyship generally refers to "a co-obligor or co-promisor in a joint or several obligation, along with the principal debtor, and is, therefore, bound with [the principal debtor] by the same in- 


\section{c. Other examples}

A suretyship in the United States may also be based on a statutory obligation. Most often this form of suretyship is present in context of leases or the rental and operation of a car or other equipment. ${ }^{142}$ For example, a Connecticut statute ${ }^{143}$ stipulates that

[a]ny person renting or leasing to another any motor vehicle owned by him shall be liable for any damage to any person or property caused by the operation of such motor vehicle while so rented or leased, to the same extent as the operator would have been liable if he had also been the owner. ${ }^{144}$

Under this statute a surety must pay all damages, including treble damages, which have been properly assessed against the vehicle operator. ${ }^{145}$

On the other hand, U.S. case law remains inconsistent on the question of whether the assignment of a real estate lease constitutes a suretyship. For example, while a Virginia state court ${ }^{\mathbf{1 4 6}}$ ruled that the assignment of a lease does not result in a suretyship, the United States Court for the Fourth Circuit of Appeals disagreed, comparing real estate leases to mortgages. ${ }^{147}$

\section{d. Enforcing involuntary suretyships}

Involuntary suretyships are not considered true suretyships, because they are not based on express agreements between the parties. As a result, involuntary suretyships may raise significant enforcement problems for the creditor or may be of no value to him. Specifically, it may be necessary for a creditor to explicitly consent to involuntary suretyships or take other affirmative steps to secure enforcement of these suretyships.

An involuntary suretyship may also lack any true benefit for the creditor. As mentioned before, any involuntary suretyship has only internal effect between the co-makers of an instrument and thus may not improve the position of the creditor. This may be different in case

strument, executed at the same time, and on the same consideration."); See also RESTATEMENT 3d, supra note $12, \$ 15$ (d).

142. Coleman v. Windham Aviation Inc., 2005 WL 1793907 (R.I. Super. July 18, 2005)(unpublished opinion)(liability of a lessee and operator of an aircraft); Fredette v. Keybank, USA, 2005 WL 1670808 (Conn. Super. June 14, 2005) (unpublished opinion) (vicarious liability on motor vehicle lessors).

143. Conn. Gen. Stat. \$14-154a (2004).

144. Id. $\$ 14-154(\mathrm{a})(\mathrm{a})$.

145. Id.

146. Lee Highway, LLC v. Virginia Garden Rests., LLC, 58 Va. Cir. 178, 181 (2002).

147. The Corner Assocs. v. W.R. Grace \& Co., 988 F. Supp. 970 (E.D. Va. 1997), aff'd 173F.3d 424 (4th Cir. 1999). 
of assignments or pledges. Here, the original principal is not only replaced without consent of the creditor, but may also involve a less creditworthy debtor. Conversely, the new principal may be more solvent, while the creditor may not be able to satisfy his debt against him due to lacking notice and the failure to recognize him as the new debtor by way of consent. U.S. courts have responded to this dilemma inconsistently. Most of the disagreement between U.S. courts center around the issue of consent. A number of courts have argued that, because an involuntary suretyship is created by operation of law consent is not necessary. ${ }^{148}$ Other courts consider the change of positions between the new principal and the original principal as a modification of the underlying obligation, which in turn would require mutuality and express consent. ${ }^{149}$ The correct answer on the need of whether or not consent is required may, however, either be found in the statutory source that prescribes the involuntary suretyship or the contractual obligation between the new and the original principal and obligor. Consent by the creditor has no effect on the contractual relationship between the new and the original principal. The latter not only remains collaterally liable to the creditor by reason of the underlying obligation, he will also have a right of indemnification against the new principal when held liable. As a result, the new principal will always be required to cover the debt. ${ }^{150}$

\section{The Liability of the Surety}

Due to the unconditional character of a suretyship under U.S. law, the extent and duration of a surety's liability are much more important when compared to that of a guarantor. The surety is jointly and severally liable with the principal obligor and has the duty to satisfy the creditors claim with respect to the underlying obligation. ${ }^{151}$ Any different rights, duties or limitations involving this liability may be defined in an express agreement between the parties. ${ }^{152}$ The terms of the suretyship agreement are thus the most important factors to determine a surety's liability under U.S. law. ${ }^{153}$

148. Westinghouse Credit Corp. v. Wolfer, 88 Cal. Rptr. 654, 657 (1970); Mead v. Sanwa Bank California, 61 Cal. App. 4th 561 (1998).

149. Tension v. Knapp, 64 S.W.2d 1071 (Tex. Civ. App. 1933); Weaver v. Oliver, 3 S.W.2d 892 (Tex. Civ. App. 1928); A.F. Shapleigh Hardware Co. v. Wells, 90 Tex. 10, 37 S.W. 411 (1896).

150. Marshall E. Tracht, 5-45 Debtor-Creditor Law \$45.03, [3][h].

151. Restatement 3d, supra note $12, \S 15(\mathrm{c})$.

152. People of the State of Illinois ex rel. Ryan v. Envtl. Waste Resources Inc., 335 Ill. App. 3d 751 (2002).

153. Angelo Iafrate Constr., LLC v. Potashnick Constr., Inc. 370 F. 3d 715 (8th Cir. 2004); Dadeland Station Assocs., Ltd. v. St. Paul Fire \& Marine Ins. Co., 383 F.3d 1273 (11th Cir. 2004). 
In addition, the liability of a surety may be extended through a tort claim or on the basis of bad faith. ${ }^{154}$

a. Default of the principal and failure to perform

Generally, under U.S. common law a surety becomes immediately liable upon default of the principal. ${ }^{155}$ The surety contracts for primary liability with the creditor, who may seek direct relief from the surety if the principal defaults on the underlying obligation. ${ }^{156}$ The creditor is not required to satisfy his debt against the principal before pursuing the surety, instead he may elect to sue the surety first and before the principal's liability is established. ${ }^{157}$ Some state jurisdictions in the United States have enacted different rules, however, requiring that the creditor must sue the principal first if a cause of action has accrued on the principal contract, and if the surety demands that the creditor pursue this action first. ${ }^{158}$ Under New York law, on the other hand, a surety can only demand that a creditor sue the principal first if the surety and the principal have so agreed in their agreement. ${ }^{159}$

\section{b. Effect of posting of additional security}

Where a creditor, in addition to a surety, has sought the posting of additional security or collateral on the underlying obligation, the creditor is prevented from suing the surety first. Rather, the creditor must proceed against the additional security first, if this can be accomplished without substantial injury. ${ }^{160}$ If the creditor fails to do so, the surety is discharged to the extent of the value of the additional security. ${ }^{161}$ The basis for this conclusion is the fact that if the creditor misapplies collateral the surety's subrogation rights may be impaired. ${ }^{162}$ This is most obvious in cases in which the creditor either loses the collateral ${ }^{163}$ or simply releases a security interest in the collateral. ${ }^{164}$

154. This extension will not be discussed here, but see, i.e., Int'l Fid.Ins. Co. v. Delmarva Systems Corp., 2001 Del Super. LEXIS 165 (May 9, 2001).

155. Koehler v. Bank of Bermuda Ltd., 2004 U.S. Dist. LEXIS 27366 (S.D.N.Y.

Mar. 9, 2005); Hardy v. Miller, 2001 Tenn. App. LEXIS 898 (Dec. 10, 2001).

156. Williams v. Blair, 2003 Ohio 4399, 2003 Ohio App. LEXIS 3907 (2003).

157. Rodehorst v. Gartner, 669 N.W.2d 679 (2003); FDIC v. Indian Creek Warehouse, J.V., 974 F. Supp. 746 (E.D. Mo. 1997).

158. California, Cal. Civ. Code Ann. \$2845, 1982 Amendment; Ohio, Ohio Rev. Code Ann. \$1341.04; Mississippi, Miss. Code Ann. \$87-5-1 (2004); Illinois, Ill. Ann.

Stat. ch. 132, $\$ 1$, as amended by P.A. $84-546$ (1985).

159. N.Y. Gen. Oblig. Law \$15-701 (McKinney 1971).

160. Washington Int'l Ins. Co. v. United States, 138 F. Supp. 2d 1314 (2001).

161. United States v. Cont'l Cas. Co., 512 F.2d 475 (5th Cir. 1975).

162. Brown v. State Far Fire \& Cas. Corp., 338 N.E.2d 427 (1975).

163. Putney Credit Union v. King, 286 A.2d 282 (1971) (involving a chattel mortgage); Conversely, see United States v. Alphagraphics Franchising, Inc. 973 F.2d 429 (5th Cir. 1992).

164. Wexler v. McLucas, 48 Cal. App. 3d Supp. 9 (1975). 
c. Res judicata

The result of an action against the principal may also be res judicata against the surety. ${ }^{165}$ This may result in either triggering the surety's liability or limiting it. The issue of res judicata particularly arises if the creditor chooses to sue or arbitrate a claim against the principal before involving the surety. In other words, the surety may be bound by a judgment on the merits against the principal, which he cannot attack. ${ }^{166}$ Some U.S. states require that the surety must be part of any action before the principle of res judicata can apply, however. ${ }^{167}$

The situation is different if a judgment was entered in favor of the principal. In the United States, such a judgment would be considered res judicata recognizing that it would be unreasonable if the creditor were allowed to seek relief against the surety after the principal's liability was denied by a court of competent jurisdiction. ${ }^{168}$ This general rule may be different, however, where the surety binds himself to the creditor through an independent obligation, such as an insurance bond. ${ }^{169}$

\section{Form Requirements and Other Rules of Construction}

With the exception of an involuntary suretyship, all suretyship agreements must comply with the Statute of Frauds and be in writing. ${ }^{170}$ The requirements are the same as for a guaranty agreement. ${ }^{171}$ At the very minimum the surety must sign the agreement as the party charged. ${ }^{172}$ Maybe most important and because the assumption of the debt is a substantial undertaking, courts in the United States will not assume that any party agreed to such an obligation. ${ }^{173}$ Therefore, the parties must clearly express their intention to act as a surety. ${ }^{174}$ While the use of the word "surety" or any other specific term is not required, the parties must clearly manifest their intention to act as a surety. ${ }^{175}$

165. Geron v. County of Nassau, 2004 U.S. Dist. LEXIS 5298 (S.D.N.Y. Mar. 20, 2004).

166. Prescott v. Coppage, 296 A.2d 150 (1972); Directors Guild of Am., Inc. v. Millennium Television Network, Inc., Co., 2001 U.S. Dist. LEXIS 22914 (C.D. Cal. Nov. 5 , 2001).

167. W. Va. Code $\$ 45-1-3(2004)$.

168. Kramer v. Morgan, 85 F.2d 96 (2nd Cir. 1936).

169. McBride v. Maryland Cas. Co., 23 A.2d 596 (E.\&A. 1942).

170. Mich. Stat. Ann. \$26.906 (1993); Cal. Civ. Code Ann. $\$ \$ 2793$ and 2794 (1993); Ill. Ann. Stats. Ch. 9, §1 (1989); Byrd v. Estate of Nelms, 2004 Tex. App. LEXIS 10351 (Nov. 17, 2004)

171. Supra, II B. 4.

172. Id.

173. Bandit Ind., 463 Mich. at 504, 620.

174. Id.

175. United States v. Fitzgerald, 938 F.2d 792, 795 (7th Cir. 1991) 
A person entering into a suretyship agreement must also have the capacity to do so. Because suretyships are contractual in nature all common law contract rules apply. However, special problems may arise in context of juridical persons, such as corporations and limited partnerships. ${ }^{176}$ As noted, a surety is a substantial undertaking under U.S. law and the capacity to enter into a suretyship agreement cannot generally be assumed. This may be of particular concern with regard to the powers of a corporate officer to enter into such an agreement. ${ }^{177}$ While a natural person with general capacity to contract has the capacity to become a secondary obligor or surety, ${ }^{178}$ relevant state law must be considered when determining the capacity of a corporate officer or a person other than a natural person. ${ }^{179}$ In addition, some U.S. state jurisdictions require that a surety must be a resident of that state and fulfill certain capital requirements in order to have the capacity to act as a surety. ${ }^{180} \mathrm{~A}$ surety may also be estopped from denying capacity when a certain level of sophistication can be assumed, such as in an insurance context. ${ }^{181}$

Finally, under U.S. law a suretyship agreement is generally interpreted in favor of the surety (strictissimi juris) as long as the surety does not gain any benefit under the suretyship or the principal agreement. ${ }^{182}$ This is not the case if the surety gets paid for his promise or is able to minimize his risk. ${ }^{183}$ For example, if the surety is a corporation organized for the purpose of doing business as a surety and receives compensation, the rule of strictissimi juris is not strictly applied. ${ }^{184}$

\section{Defenses and Termination}

A guarantor or surety has a number of different defenses against the creditor or the principal. The defenses include compelling performance by the principal, seeking indemnification from the principal after paying his debt, reimbursement, subrogation, and termination.

176. Restatement 3d, supra note $12, \S 10$, Cmt. (b).

177. Id.

178. While a family member can generally act as a surety of another, this is not always the case for married women, who may be considered incompetent to be a surety in some U.S. states. See, i.e., Dorman v. Carnes, 265 Ky. 361, 96 S.W.2d 869 (1936); Judson v. Duran, 231 Ga 206 (1973); Nat'l Bank of Rochester v. Meadowbrook Heights, Inc., 80 Mich. App. 777 (1978).

179. RESTATEMENT 3d, supra note $12, \S 10(1)$ and $\$ 10(2)$.

180. Ohio Rev. Code Ann. \$1341.01; Ariz. Rev. Stat. \$7-101 (2004); Rev. Code Wash. (ARCW) §19.72.020 (2004); Minn. Stat. \$574.01 (2004).

181. Code of Ala. \$27-24-7 (2005); Kan. Stat. Ann. \$78-105(2003); Ky. Rev. Stat. $\$ 304.21-080$ (2004); 24-A Me. Rev. Stat. \$3105 (2004); Nev. Rev. Stat. §691B.030(2004); N.M. Stat. Ann. §46-6-5 (2005); S.C. Code. Ann. §38-15-70 (2004).

182. Joseph Thomas, Inc. v. Graham, 842 S.W.2d 343 (Tex. Ct. App. 1992).

183. Int'l Fid. Ins. Co. v. County of Rockland, 98 F. Supp. 2d 400, 405-06 (2000).

184. Id. 


\section{A. Exoneration and Indemnification}

As between the principal and the guarantor or surety, both the guarantor and surety can seek exoneration through discharge of the underlying obligation or ask for indemnification and reimbursement as a form of restitution. ${ }^{185}$

\section{Exoneration}

Under U.S. law, before seeking restitution, the surety has the right to compel performance by the principal on the underlying obligation. This right may be expressly included in a statute ${ }^{\mathbf{1 8 6}}$ or based on the common law principle of equity. ${ }^{187}$ In other words, the surety is only secondarily liable and does not take the principal's obligation for its own. ${ }^{188}$ The surety only pays on the principal's behalf; he is obligated to pay only when the obligor fails to pay the obligee in a timely manner. ${ }^{189}$

\section{Restitution}

a. Reimbursement

If the surety is called on to pay the principal's debt, the surety has the right to recover from the principal for any payments made or when the surety's property is used to satisfy the principal's obligation. ${ }^{190}$ Generally considered to be an equitable right, many U.S. jurisdictions also provide for statutory reimbursement rights. ${ }^{191}$ Most important, a surety can only claim reimbursement rights if he conducts a reasonable investigation of the claim before making any payments. ${ }^{192}$ Some limitations of the right also exist with regard to the reasonableness of certain expenses, such as attorney fees ${ }^{193}$ or when the principal files for bankruptcy. ${ }^{194}$

\section{b. Indemnification}

The right of reimbursement may also be part of an indemnity agreement entered into between the principal and the guarantor or

185. RESTATEMENT 3d, supra note $12, \$ 18$.

186. Ohio Rev. Code Ann. §1341.19 (Page 1971); Cal. Civ. Code Ann. §2846 (1974).

187. M \& T Elec. Contractors, Inc. v. Capital Lighting \& Supply, Inc., 267 B.R. 434, 447 (2001) (implied right to performance).

188. Id. at 446; See also, In re Farley Inc., 236 F.3d 359, 361 (7th Cir. 2000).

189. Id.; See also, Restatement 3d, supra note 12 , \$18 Cmt. a.

190. U.C.C. $\$ 3-419(\mathrm{e})$; REstatement 3d, supra note $12, \S 22$.

191. Code of Ala. §8-3-5 (2004); Cal. Civ. Code Ann. $\$ 2847$ (2005); La. Civ. Code Art. 3049; N.D. Cent. Code, $\$ 22-03-10$ (2005).

192. PSE Consulting Inc. v. Frank Mercede \& Sons, Inc., 838 A.2d 135 (2004); Bell BCI Co. v. Old Dominion Demolition Corp., 2003 U.S. Dist. LEXIS 22911 (E.D. Va. 2003).

193. Pacific Indem. Co. v. Harper, 14 Cal. 2d 379, 384 (1939).

194. Walter Downs, A Surety's Basic Rights and Remedies, 15 Defense L. J. 139, $172(1966)$. 
surety, which is typically the norm. If executed, the surety may only rely on the exact terms of the indemnity agreement and common law principles do not apply. ${ }^{195}$ Note, however, that the agreement may incorporate common law principles, such as good faith. ${ }^{196}$

\section{c. Subrogation}

Subrogation is the surety's equitable right to claim the rights of the creditor against the principal. ${ }^{197}$ Upon payment, the surety stands in the shoes of the creditor ${ }^{198}$ and can assert the rights of the creditor against the principal. ${ }^{199}$ Subrogation is independent and does not affect the surety's right to reimbursement from the principal. ${ }^{200}$ Rather, subrogation affects the priority of the surety when compared to other creditors of the principal. ${ }^{201}$ As such, a surety is "subrogated to the rights and remedies of its principal against third parties, where those rights arise from or are closely related to the debt that the surety was required to pay under the suretyship agreement."202

\section{B. Termination Rights}

Under U.S. law, termination rights related to guaranty or suretyship agreements are considered suretyship defenses, which may result in the surety's discharge as a secondary obligor. ${ }^{203}$ While the satisfaction of the underlying obligation will generally terminate any suretyship, the same may result from actions taken by the parties involved.

\section{Release of the Principal}

If a creditor grants a general release to the principal, this release may also function as a release for the surety. ${ }^{204} \mathrm{~A}$ creditor may, however, retain his right against the surety and prevent his discharge. ${ }^{205}$ More specifically, in order to pursue the surety after the release of the principal the creditor must expressly reserve his right against the surety and demonstrate that he did not intend to release him as a

195. Fireman's Ins. Co. of Newark v. Todesca Equip. Co., Inc., 310 F.3d 32, 37 (1st Cir. 2002).

196. Anderson v. United States Fid. \& Guar. Co., 600 S.E.2d 712 (2004).

197. Simpson, supra note 23 , at $\$ 47$.

198. Hanover Ins. Co. v. Corrpro Cos., Inc., 221 F.R.D. 458, 460 (E.D. Va 2004).

199. Flojo Int'l, Inc. v. Lassleben, 4 Cal.App.4th 713 (1992).

200. Simpson, supra note 23 , at $\$ 48$.

201. Assoc. Home Equity Servs. v. Franklin Nat'l Bank, 2002 Tenn. App. LEXIS 207, 9-10 (Mar. 26, 2002).

202. In re Estate of Bishop, 2004 Ohio 2197, P27 (2004).

203. In re Murchison, 102 B.R. 545 (Bankr. N.D. Texas 1988).

204. U.C.C. $\$ 3-605(a)(2)$.

205. Id. 
secondary obligor. ${ }^{206}$ However, even if the surety remains liable to the creditor, the surety is discharged to "the extent of the value of the consideration for the release" 207 of the principal. A different outcome may result if the surety was compensated, limiting any potential discharge to the extent of her injury (pro tanto) ${ }^{208}$ or the proof of prejudice. ${ }^{209}$

\section{Modification of the Underlying Obligation}

Any modification or alteration of the principal contract without the consent of the surety ${ }^{210}$ may also operate as a release for the surety. ${ }^{211}$ Certain modifications or alterations may be considered beneficial for the surety, however.

\section{a. Due date extension}

Generally, the extension of a due date may be considered beneficial for the surety. Presumably, the principal cannot only avoid his own default on the underlying obligation; he may also avoid triggering the payment obligation of the surety. Accordingly, a surety is only "discharged to the extent that the extension would otherwise cause the [surety] a loss." 12 The extension may cause a loss if the financial situation of the principal deteriorates further and the surety may no longer be able to recover from the principal. ${ }^{213}$ Note, that if the modification extends the time of performance for the creditor rather than the principal, the surety is discharged, unless she consents to this modification or has waived her defenses. ${ }^{214}$

\section{b. Material modification}

A material modification is one that substantially changes the terms of the underlying obligation, such as the nature, meaning or legal effect of the contract. ${ }^{215}$ Any such material change traditionally resulted in a general discharge of the surety under U.S. law. ${ }^{216}$ In fact, it was irrelevant whether a material modification benefited or injured the surety as long as it constituted an essential deviation or

206. Chicago Title Ins. Co. v. Lumbermen's Mut. Cas. Co., 707 A.2d 913, 920 (1998).

207. U.C.C. $\$ 3-605(a)(3)$; Restatement 3d, supra note 12, §39.

208. Zuni Const. Co. v. Great Am. Ins. Co., $86 \mathrm{Nev}$. 364, 367 (1970).

209. Reliance Ins. Co. v. Colbert, 365 F.2d 530, 535 (D.C. 1966).

210. United States Fid. \& Guar. Co. v. Braspetro Oil Serv. Co., 369 F.3d 34 (2nd Cir. 2004).

211. U.C.C. $\$ 3-605(c)$; Restatement 3d, supra note 12, $\$ 41$.

212. U.C.C. $\$ 3-605(\mathrm{~b})(2)$; RESTATEMENT 3d, supra note $12, \$ 40$.

213. U.C.C. $\$ 3-605$, Cmt. 5 .

214. Rabinovici v. Solomon, 2002 U.S. Dist. LEXIS 22260 (E.D. Pa. Nov. 4, 2002).

215. Cont'l Bank v. Axler, 510 A.2d 726, 729 (Pa. Super. 1986).

216. Amerisourcebergen Drug Corp. v. Meier, 2004 U.S. Dist. LEXIS 25243 (E.D. Pa. Dec. 14, 2004). 
change of the contract terms. ${ }^{217}$ Today, under the modern view only the proof of loss is required, resulting in discharge to the extent of that loss only. ${ }^{218}$ However, if the modification imposes new obligations on the surety, which substantially increase risk of loss, U.S. courts may grant a general discharge. ${ }^{219}$ Note, in some U.S. jurisdictions any changes that increase the obligations of the principal will generally result in a discharge of the surety, regardless of the impact of that change on the surety. ${ }^{220}$

\section{Impairment of Collateral}

Under U.S. law, a surety is further entitled to the benefit of every security, including any collateral, held by the creditor as additional security. ${ }^{221}$ If the creditor impairs the collateral or releases it prematurely, the surety is discharged to the extent of the impairment. ${ }^{222}$ The creditor has the obligation to protect the collateral and must ensure that, upon default of the principal, the collateral is properly applied to the remaining debt. ${ }^{223}$ By impairing the collateral the creditor “impairs the surety's ability to be made whole through subrogation if the surety is later called upon to discharge the underlying obligation." 224 The surety is only limited by burden of proof. He must prove the impairment, but can do so by showing that the creditor failed to perfect or maintain the collateral or to obtain substitute collateral. $^{225}$

\section{Waiver}

A surety may effectively waive its suretyship defenses or right to discharge through consent. ${ }^{226}$ Consent may be obtained contemporaneously or in advance of a workout and does not require any particular language. ${ }^{227} \mathrm{~A}$ waiver can be included in the suretyship or any separate agreement and may be express or implied from the circumstances. $^{228}$ It is standard practice in the United States to include

217. Cross v. Allen, 141 U.S. 528, 540 (1891).

218. U.C.C. $\S 3-605(c)(2)$.

219. Autumn Manor, Inc. v. Jones, 2003 U.S. Dist. LEXIS 16762 (D. Kan. Aug. 19, 2003).

220. Cal. Civ. Code $\$ 2819$ (1974).

221. St. Paul Fire \& Marine Ins. Co. v. New Jersey Bank \& Trust Co., 250 A.2d 57 (Law Div. 1969).

222. U.C.C. §3-605(d); Restatement 3d, supra note 12, §42; Trust of Strand v. WelCo Group, Inc., 86 P.3d 818 (2004).

223. Pennsylvania Nat'l Mut. Cas. Ins. Co. v. City of Pine Bluff, 354 F.3d 945, 953 (8th Cir. 2004).

224. Id.

225. For additional examples, see U.C.C. \$3-605(d) and Restatement 3d, supra note $12, \S 42(2)(\mathrm{a})$-(d).

226. U.C.C. §3-605(f); REstATEMENT 3d, supra note 12 , §48.

227. Restatement 3d, supra note $12, \$ 48$, Cmt. b.

228. Id.; See also U.C.C. \$3-605, Cmt. 9. 
waivers in notes prepared by financial institutions thereby effectively foreclosing the availability of any defenses for a surety or guarantor in this context. ${ }^{229}$

\section{CONClusion}

U.S. law does not clearly distinguish between guaranties or suretyships given by private or commercial parties. The only aspect of consumer protection is included in certain notice requirement established by the Federal Trade Commission or in some U.S. State jurisdictions. Guaranties and suretyships are simply considered third-party beneficiary contracts to which all common law contract principles apply. While the Uniform Commercial Code and the Restatement 3rd provide a framework for a uniform body of law, the differences in the codification and substantive content of suretyship laws among all U.S. States is significant. The same is true, with regard to the case law at the federal and state levels.

229. Id. 